\title{
Alterations in insulin-induced postreceptor signaling in adipocytes of the Otsuka Long-Evans Tokushima fatty rat strain
}

\author{
T Ishizuka, A Miura, K Kajita, K Yamada, H Wada, S Itaya, \\ Y Kanoh, M Ishizawa, M Kimura and K Yasuda
}

The Third Department of Internal Medicine, Gifu University School of Medicine, Tsukasamachi 40, Gifu 500, Japan

(Requests for offprints should be addressed to T Ishizuka)

\begin{abstract}
The Otsuka Long-Evans Tokushima fatty (OLETF) rat is a new spontaneous non-insulin-dependent diabetes mellitus (NIDDM) model rat strain developed in Tokushima, Japan. After 18 weeks of age, decreases of $45 \%$ and $40 \%$ respectively in insulin- and phorbol ester-stimulated $\left[{ }^{3} \mathrm{H}\right] 2$-deoxyglucose (DOG) uptake were observed, compared with those in Long-Evans Tokushima (LETO) rats (control). Insulin-specific binding and $95 \mathrm{kDa}$ autophosphorylation of insulin receptor in OLETF rats were not different from those in LETO rats. Insulin-induced diacylglycerol (DG) production and Mono Q columnpurified protein kinase $\mathrm{C}(\mathrm{PKC})$ translocation in adipocytes of OLETF rats were decreased compared with those of LETO rats. Insulin-induced PKC $\beta$ translocation from cytosol to membrane was also decreased in adipocytes of
\end{abstract}

OLETF rats. Increases of the PKC $\beta \mathrm{I}, \beta \mathrm{II}, \varepsilon$ and $\zeta$ isoforms in membranes of OLETF rats were markedly smaller than those of LETO rats. Analysis of mRNA levels of PKC isoforms in adipocytes of OLETF rats showed decreases of basal level and insulin-induced delayed responses of PKC $\beta$ I, $\beta I$ I, $\varepsilon$ and $\zeta$ mRNA in OLETF rats. On the other hand, insulin- or phorbol ester-induced phosphatidylinositol 3-kinase (PI 3-kinase) activation was decreased in adipocytes of OLETF rats compared with those of LETO rats. These results suggest that insulin resistance in OLETF rats, a spontaneous NIDDM model rat, may be associated with deterioration of insulin-induced DGPKC signaling and subsequent decrease in PI 3-kinase activation.

Journal of Endocrinology (1998) 156, 1-13

\section{Introduction}

Activation of protein kinase $\mathrm{C}$ (PKC) is a major mechanism for transduction of signals (Nishizuka 1988). Agonists such as hormones, neurotransmitters, and growth factors stimulate the hydrolysis of various phospholipids in the plasma membrane to generate diacylglycerol (DG) which causes PKC to translocate from the cytosol to specific membrane sites. In particular, insulin and phorbol esters provoke increases in membrane-associated PKC in rat adipocytes (Ishizuka et al. 1989, Egan et al. 1990). Moreover, it has previously been reported that PKC $\beta$ is translocated from cytosol to membrane in response to treatment of rat adipocytes (Ishizuka et al. 1989) and soleus muscle (Ishizuka et al. 1990, 1991) with insulin and/or 12-O-tetradecanoyl phorbol-13-acetate (TPA). However, it is known that cells contain various PKC isoforms (Ishizuka et al. 1992).

It is also well accepted that phosphatidylinositol 3-kinase (PI 3-kinase) is associated with and activated by a number of proteins containing tyrosine kinase activities, including the receptor for platelet-derived growth factor (Whitman et al. 1987), insulin (Endeman et al. 1990,
Ruderman et al. 1990), and the products of oncogenes (Varticovski et al. 1989). PI 3-kinase, which consists of an $85-\mathrm{kDa}$ regulatory subunit and a $110-\mathrm{kDa}$ catalytic subunit (Carpenter \& Cantley 1990, Escobedo et al. 1991, Hiles et al. 1992), is believed to play important roles in the transduction of mitogenic signals (Cantley et al. 1991). Although receptor-mediated activation of PI 3kinase was also found in N-formyl-Met-Leu-Phe (fMLP)stimulated human neutrophils (Traynor-Kaplan et al. 1989) and thrombin-stimulated human platelets (Kucera \& Rittenhouse 1990), the physiological role of PI 3-kinase in these cells is still uncertain.

Despite the physiological importance of insulin sensitive tissues such as liver, muscle and adipose tissue, much remains unknown about the post-receptor signaling system in these tissues. Elucidation of the signal pathway is especially relevant in understanding the mechanism underlying insulin resistance in skeletal muscle and adipocytes. One such pathological state is the obese, hyperinsulinemic syndrome that is commonly associated with non-insulin-dependent diabetes mellitus (NIDDM). Previously, we reported that insulin-induced PKC activation in adipocytes of old-obese rats was decreased, 
Table 1 Primers used in mRNA amplification

\begin{tabular}{|c|c|c|}
\hline & Sequences & $\begin{array}{l}\text { Fragment size } \\
\text { (bases) }\end{array}$ \\
\hline \multicolumn{3}{|c|}{ Oligonucleotide } \\
\hline PKC $\beta I-5^{\prime}$ & СTTTGGCATGTGTAAAGAGAATATCTGGGA & 442 \\
\hline PKC $\beta I-3^{\prime}$ & GTCGAAGTTGGAGGTGTCTCGCTTGTCTCT & \\
\hline PKC $\beta I-5^{\prime}$ & CTTTGGCATGTGTAAAGAGAATATCTGGGA & 571 \\
\hline PKC $\beta \|-3^{\prime}$ & TTAGCTCTTGACTTCGGGTTTTAAAAATTC & \\
\hline $\mathrm{PKC} \varepsilon-5^{\prime}$ & TCATCGATCTCTCGGGATCATCGG & 733 \\
\hline $\mathrm{PKC} \varepsilon-3^{\prime}$ & CGGTTGTCAAATGACAAGGCATTC & \\
\hline PKC $\zeta-5^{\prime}$ & CGATGGGATGGATGGGATCAAAATC & 685 \\
\hline 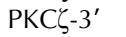 & TTCAGTATTCATGTCAGGGTTGTCT & \\
\hline Hprt-5' & GTTGGATACAGGCCAGACTTTGTTG & 162 \\
\hline Hprt-3' & GATTCAACTTGCGСTCATCTTAGGC & \\
\hline
\end{tabular}

Table 2 General characteristics of OLETF and LETO rats

\begin{tabular}{|c|c|c|c|c|}
\hline & $\begin{array}{l}\text { Age } \\
\text { (week) }\end{array}$ & $\begin{array}{l}\text { Body weight } \\
\text { (g) }\end{array}$ & $\begin{array}{l}\text { Plasma glucose } \\
(\mathrm{mM})\end{array}$ & $\begin{array}{l}\text { IRI } \\
(\mathrm{pM})\end{array}$ \\
\hline \multicolumn{5}{|l|}{$\begin{array}{l}\text { Rat } \\
\text { strain }\end{array}$} \\
\hline \multirow[t]{5}{*}{ OLETF } & 8 & $270 \pm 38$ & $7 \cdot 0 \pm 2 \cdot 6$ & $120 \pm 23$ \\
\hline & 12 & $395 \pm 42$ & $7 \cdot 5 \pm 2 \cdot 4$ & $144 \pm 26$ \\
\hline & 18 & $510 \pm 60^{*}$ & $11 \cdot 2 \pm 3 \cdot 6^{*}$ & $250 \pm 38^{*}$ \\
\hline & 24 & $590 \pm 68^{* *}$ & $12 \cdot 3 \pm 4 \cdot 1^{* *}$ & $403 \pm 62^{* *}$ \\
\hline & 30 & $625 \pm 79^{* *}$ & $14 \cdot 3 \pm 5 \cdot 1^{* *}$ & $450 \pm 71^{* *}$ \\
\hline \multirow[t]{5}{*}{ LETO } & 8 & $225 \pm 37$ & $6 \cdot 7 \pm 2 \cdot 3$ & $115 \pm 28$ \\
\hline & 12 & $348 \pm 46$ & $6 \cdot 8 \pm 2 \cdot 6$ & $122 \pm 32$ \\
\hline & 18 & $422 \pm 48$ & $6 \cdot 9 \pm 2 \cdot 8$ & $183 \pm 40$ \\
\hline & 24 & $485 \pm 53$ & $7 \cdot 0 \pm 3 \cdot 1$ & $250 \pm 42$ \\
\hline & 30 & $496 \pm 56$ & $7 \cdot 1 \pm 2 \cdot 9$ & $270 \pm 63$ \\
\hline
\end{tabular}

${ }^{*} P<0 \cdot 05,{ }^{*} P<0 \cdot 01$ compared with LETO (Student's $t$-test).

compared with that in young-lean rats (Ishizuka et al. 1993). Moreover, a defect in skeletal muscle PI 3-kinase in obese insulin-resistant mice was also reported (Heydrick et al. 1993).

A spontaneous long-term hyperglycemic rat with diabetic complications, the Otsuka Long-Evans Tokushima fatty (OLETF) strain has been established (Kawano et al. 1992). Clinical and pathological features of disease in OLETF rats resemble those of human NIDDM. However, in the OLETF rat abnormalities of insulin-induced postreceptor signaling remain unclear. In the present study, we have shown that the insulin-induced DG-PKC signaling was diminished in adipocytes of OLETF rats.

\section{Materials and Methods}

\section{Materials}

Pork insulin was obtained from Novo (Copenhagen, Denmark). $\left[\gamma_{-}{ }^{32} \mathrm{P}\right]$ ATP $(3000 \mathrm{Ci} / \mathrm{mmol})$ and $\left[1,2{ }^{3} \mathrm{H}\right] 2-$ deoxyglucose $\left(\left[{ }^{3} \mathrm{H}\right] 2-\mathrm{DOG}\right),\left[2{ }^{3} \mathrm{H}\right] \mathrm{glycerol}(5 \mathrm{Ci} / \mathrm{mmol})$, $\left[9,10-{ }^{3} \mathrm{H}\right]$ palmitic acid $(30-60 \mathrm{Ci} / \mathrm{mmol})$ and $\mathrm{L}-[1-$ ${ }^{14} \mathrm{C}$ ]glucose $(47 \mathrm{mCi} / \mathrm{mmol})$ were purchased from New
England Nuclear (Boston, MA, USA). Phosphatidylserine (PS), diolein, histone (type III-S), phenylmethylsulfonyl fluoride (PMSF), leupeptin, 12-O-tetradecanoyl phorbol13-acetate (TPA), BSA, D-glucose, ATP and goat antirabbit $\gamma$-globulin complexed to alkaline phosphatase were purchased from Sigma Chemical Co. (St Louis, MO, USA). Silicon oil was obtained from Aldrich Chemical Co. (Milwaukee, WI, USA). PKC $\beta, \varepsilon$ and $\zeta$ antibodies were purchased from Gibco BRL Products (Grand Island, NY, USA). PKC $\beta$ I and $\beta$ II were purchased from Santa Cruz Co (CA, USA). All other chemicals were of reagent grade or better.

\section{Adipocyte experiments}

Male OLETF rats, an animal model of human NIDDM, and Long-Evans Tokushima (LETO) rats, achieved by selective breeding of the control line which was obtained by different original matings from those for OLETF rats, both strains originating from the same colony of LongEvans rats (Kawano et al. 1992), were allowed to feed ad libitum and were killed by decapitation. Free adipocytes were isolated by collagenase digestion of rat epididymal fat 

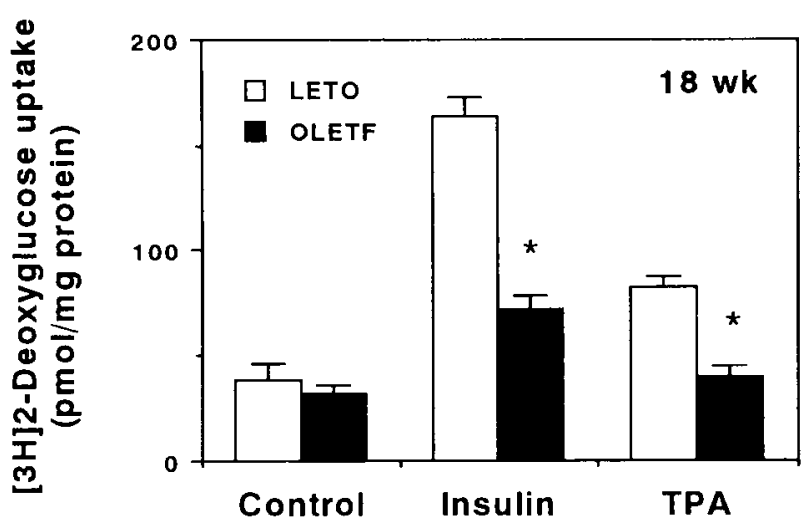

Figure 1 Insulin- or TPA-stimulated $\left[{ }^{3} \mathrm{H}\right] 2$-DOG uptake in adipocytes of OLETF and LETO rats at 18 weeks of age. Isolated adipocytes were washed and preincubated in glucose-free KRP containing $1 \%$ BSA for $30 \mathrm{~min}$. $\left[{ }^{3} \mathrm{H}\right] 2$-DOG was then added to a cell suspension, and uptake of $\left[{ }^{3} \mathrm{H}\right] 2$-DOG was measured over $1 \mathrm{~min}$. Unstimulated $\left[{ }^{3} \mathrm{H}\right] 2$-DOG uptake is shown as Control. $\left[{ }^{3} \mathrm{H}\right] 2$-DOG uptake in adipocytes of OLETF (open bars) and LETO rats (solid bars) at 18 weeks of age during stimulation with $10 \mathrm{nM}$ insulin and $1 \mu \mathrm{M}$ TPA for 30 min was measured. Results are expressed as pmol glucose/mg protein and represent three to four separate experiments, each conducted in triplicate. Values are means \pm S.E. ${ }^{*} P<0 \cdot 01$ (Student's $t$-test).

pads (Rodbell 1964) in Krebs-Ringer phosphate (KRP) buffer (pH 7.4) containing $127 \mathrm{mM} \mathrm{NaCl}, 12.3 \mathrm{mM}$ $\mathrm{NaH}_{2} \mathrm{PO}_{4}, 5.1 \mathrm{mM} \mathrm{KCl}, 1.3 \mathrm{mM} \quad \mathrm{MgSO}_{4}, 1.4 \mathrm{mM}$ $\mathrm{CaCl}_{2}, 3 \% \mathrm{BSA}$, and $2.5 \mathrm{mM}$ glucose. Adipocytes were washed and preincubated at $37^{\circ} \mathrm{C}$ in glucose-free KRP buffer containing 1\% BSA for $30 \mathrm{~min}$, and then incubated with or without $10^{-6} \mathrm{M}$ TPA, $10 \mathrm{nM}$ insulin for $\left.30 \mathrm{~min} .{ }^{3} \mathrm{H}\right] 2-\mathrm{DOG}(0.08 \mu \mathrm{Ci})$ and unlabeled 2-DOG $(0.05 \mathrm{mM})$ were then added to $300 \mu \mathrm{l}$ of a $10 \%(\mathrm{vol} / \mathrm{vol})$ adipocyte suspension, and uptake of $\left[{ }^{3} \mathrm{H}\right] 2-\mathrm{DOG}$ was measured over $1 \mathrm{~min}$ (Olefsky 1978). In PKC experiments, reactions were terminated by addition of $10 \mathrm{ml}$ ice-cold buffer I $(20 \mathrm{mM}$ Tris-HCl, pH 7.5, 0.25 M sucrose, $1.2 \mathrm{mM}$ EGTA, $0.1 \mathrm{mM}$ PMSF, $20 \mu \mathrm{g} / \mathrm{ml} \mathrm{leu-}$ peptin, $20 \mathrm{mM}$ mercaptoethanol) at the indicated time. The adipocytes were washed twice and homogenized in buffer I. Homogenates were centrifuged at $1000 \boldsymbol{g}$ for $2 \mathrm{~min}$, and floating fatty materials were removed. Resultant homogenates were centrifuged at $105000 \boldsymbol{g}$ for $60 \mathrm{~min}$ to obtain cytosol and membrane fractions as described below.

\section{Insulin binding studies}

Isolated adipocytes were incubated with ${ }^{125}$ I-insulin (2000 Ci/mmol, Amersham, Tokyo, Japan) and unlabeled insulin $(1$ to $1000 \mathrm{nmol} / \mathrm{l})$ in plastic tubes at $25^{\circ} \mathrm{C}$ in a shaking water bath for $60 \mathrm{~min}$. Incubations were terminated by removing $300 \mu \mathrm{l}$ aliquots from the cell suspension and rapidly centrifuging the cells in plastic microfuge tubes to which $100 \mu \mathrm{l}$ silicone oil had been added. The cells were then removed, and the radioactivity was determined. All studies were performed in triplicate.

\section{Autophosphorylation of insulin receptor}

Isolated adipocytes were homogenized in lysis buffer (50 mM HEPES, pH 7·4, $150 \mathrm{mM} \mathrm{NaCl}, 1 \%$ Triton $\mathrm{X}-100,1 \mathrm{mg} / \mathrm{ml}$ Bacitracine, $20 \mathrm{mM}$ (p-amidinophenyl)methanesulphonyl fluoride hydrochloride, $5 \mathrm{mM}$ EDTA, $5 \mathrm{mM}$ EGTA, $20 \mathrm{mM}$ sodium pyrophosphate, $1 \mathrm{mM}$ orthovanadate, $20 \mathrm{mM} \mathrm{NaF}$ ), and then centrifuged at 15000 r.p.m. for $20 \mathrm{~min}$ to obtain the supernatant. The resultant supernatant was placed on an anti-insulin receptor antibody-coated U-bottom plate (Ebina et al. 1987) and incubated for $4 \mathrm{~h}$. After washing the insulin receptor four times, $20 \mu \mathrm{l} 10^{-6} \mathrm{M}$ insulin and kinase buffer (50 mM HEPES, $\mathrm{pH} 7 \cdot 5,150 \mathrm{mM} \mathrm{NaCl}, 5 \mathrm{mM} \mathrm{MgCl}_{2}$, $\left.5 \mathrm{mM} \mathrm{MnCl} 2,1 \mu \mathrm{M}\left[\gamma-{ }^{32} \mathrm{P}\right] \mathrm{ATP}\right)$ were added to the insulin receptor and incubated for $60 \mathrm{~min}$ at room temperature. The sample was subjected to SDS-PAGE and autoradiographed to obtain $95 \mathrm{kDa}$ phosphorylating activity.

\section{PKC studies}

Rat adipocytes isolated as above were homogenized with a polytron homogenizer in buffer I. The homogenates were centrifuged for $60 \mathrm{~min}$ at $105000 \mathrm{~g}$ to separate the cytosol and membrane fractions. After membranes were resuspended in buffer I containing $5 \mathrm{mM}$ EGTA, $2 \mathrm{mM}$ EDTA, and $1 \%$ Triton $\mathrm{X}-100$ for $30 \mathrm{~min}$ at $4{ }^{\circ} \mathrm{C}$, they were sonicated, and centrifuged at $105000 \mathrm{~g}$ to obtain solubilized membrane fractions. To measure PKC enzyme activity of adipocytes, cytosol or solubilized membrane fractions were diluted with $20 \mathrm{mM}$ Tris- $\mathrm{HCl}$ buffer (pH 7.5) containing 0.5 mM EGTA, $0.5 \mathrm{mM}$ EDTA, and $10 \mathrm{mM}$ 2-mercaptoethanol (buffer II). The samples were then applied to a Mono Q column $(0.5 \times 0.5 \mathrm{~cm}$, Pharmacia HR 5/5) that was equilibrated with buffer II and connected to a high performance liquid-chromatography system, as described previously (Ishizuka et al. 1989, 1990). PKC was eluted by application of a $20 \mathrm{ml}$ linear gradient of $\mathrm{NaCl}(0-0.7 \mathrm{M})$ in buffer II at a flow rate of $0.65 \mathrm{ml} /$ min. Fractions of $1 \mathrm{ml}$ were collected, and PKC activity of each fraction was assayed by measuring the phosphorylation of histone III-S, as described previously (Ishizuka et al. 1989).

Activation of PKC in rat adipocytes was also assayed by changes in the subcellular distribution of immunoreactive PKC using the methods described previously (Ishizuka et al. 1989, 1990). Equal amounts of cytosol or membrane fractions were prepared as described above and subjected to sodium dodecyl sulfate-polyacrylamide gel electrophoresis (SDS-PAGE), transferred to nitrocellulose, and incubated first with rabbit polyclonal antiserum raised to 


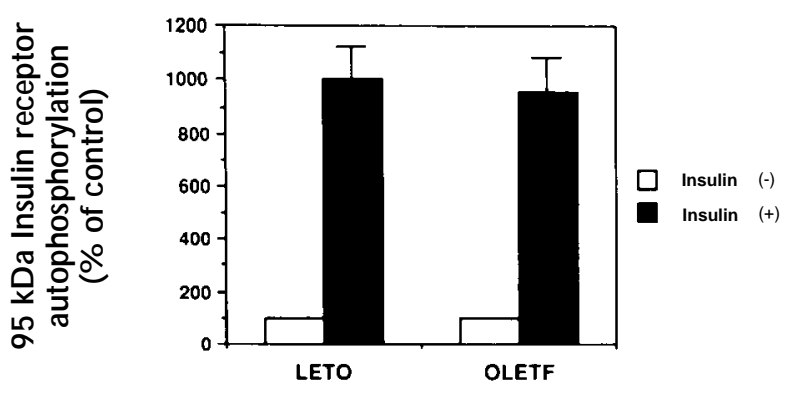

\section{Insulin receptor \\ Tyrosine kinase \\ in rat adipocytes}
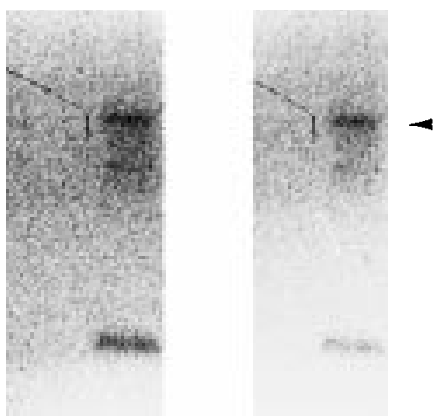

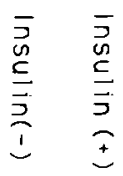

$\begin{array}{ll}\bar{J} & \overline{0} \\ \stackrel{0}{c} & \vdots \\ \vdots & \vdots \\ & \pm\end{array}$

LETO

OLETF

Bound insulin (fmol/tube)

Figure 2 Insulin-specific binding and insulin receptor tyrosine kinase activity in adipocytes of OLETF and LETO rats at 18 weeks of age. Isolated adipocytes ( $10 \%$ cell suspension) were incubated with ${ }^{125}$ I-insulin in various concentrations of unlabeled insulin $(1$ to $1000 \mathrm{nM})$ at $25^{\circ} \mathrm{C}$ for $60 \mathrm{~min}$. Cells specifically binding ${ }^{125}$ I-insulin were removed from the cell suspension as indicated in Materials and Methods, radioactivity was counted, and insulin specific binding was analyzed by Scatchard analysis (lower left panel). Autophosphorylation of insulin receptor $\beta$ subunit was measured using immunoprecipitation with anti-insulin receptor antibody as described in Materials and Methods (right panel). Densitometric data are means \pm S.E. of three separate determinations (upper left panel).

synthetic peptide specific to each $\mathrm{PKC} \beta, \varepsilon, \zeta$ (Gibco BRL, Grand Island, NY, USA), $\beta$ I, $\beta$ II (Santa Cruz, CA, USA) and secondly with goat anti-rabbit $\gamma$-globulin complexed to alkaline phosphatase. Specificities for $\operatorname{PKC} \beta, \beta \mathrm{I}$, $\beta I I, \varepsilon$, and $\zeta$ antibodies were verified by added immunogenic peptide. As reported (Ishizuka et al. 1989), this immunoblotting method detected a single major immunoreactive band that comigrated on SDS-PAGE and blotted identically with purified rat brain $80000-M_{\mathrm{r}}$ (PKC $\beta, \beta \mathrm{I}$, $\beta \mathrm{II}$ and $\zeta$ ) and $90000-M_{\mathrm{r}}$ (PKC $\varepsilon$ ) PKCs. The intensity of immunoreactivity was scanned with a laser densitometer (Pharmacia LKB Biotechnology, Tokyo, Japan) to determine the relative value.

\section{Incorporation of $\left[^{3} \mathrm{H}\right]$ glycerol into diacylglycerol}

Adipocytes were incubated for $30 \mathrm{~min}$ in $0.5 \mathrm{ml}$ KRP buffer. $\left[{ }^{3} \mathrm{H}\right]$ Glycerol $(10 \mu \mathrm{Ci})$ or $\left[{ }^{3} \mathrm{H}\right]$ palmitic acid was then added, and after prelabeling adipocytes for $15 \mathrm{~min}$ or
$60 \mathrm{~min}$, vehicle (controls) or insulin was added, and the incubation was continued for the indicated times. Reactions were stopped by the addition of methanol (final concentration, 50\%). Samples were transferred to glass tubes. Chloroform (2 vol) was added, and extraction of the lipids was performed as described previously (Hoffman et al. 1991).

\section{Diacylglycerol content in adipocytes}

Diacylglycerol content was measured by the method of Preiss et al. (1986). The reaction was stopped by the addition of methanol (final concentration, 50\%). Samples were transferred to glass tubes, and cell suspensions were homogenized with a sonicator. Chloroform $(2 \mathrm{vol})$ was added, and extraction of the lipids was performed. The resultant samples were washed, evaporated, sonicated in $20 \mu \mathrm{l}$ solution I (7·5\% octyl- $\beta$-glucoside, $5 \mathrm{nM}$ cardiolipin and $1 \mathrm{mM}$ ) diethylene triaminepentaacetic acid 
Table 3 Effect of insulin on $\left[{ }^{3} \mathrm{H}\right]$ glycerol incorporation into DG in adipocytes of OLETF and LETO rats at 18 weeks of age. Adipocytes were prelabeled for $15 \mathrm{~min}$ or $60 \mathrm{~min}$ with $10 \mu \mathrm{Ci} /$ sample $\left[{ }^{3} \mathrm{H}\right]$ glycerol (a) or $5 \mu \mathrm{Ci} /$ sample $\left[{ }^{3} \mathrm{H}\right]$ palmitic acid (b), and then incubated in the presence or absence of insulin $(10 \mathrm{nM})$ for the times indicated. Insulin-induced alterations of DG content (c) were also measured as indicated in Materials and Methods. Results are depicted as a percentage of time-matched control values (in parentheses) and represent three separate experiments, each conducted in triplicate (means \pm S.E.)

\section{OLETF rats}

(c.p.m./mg protein)

Time

(min)

(a) Insulin-stimulated $\left[{ }^{3} \mathrm{H}\right]$ glycerol incorporation into diacylglycerol
$56951 \pm 5436(100 \%)$
$66062 \pm 8544(116 \%)$
$80302 \pm 11390(141 \%)$
$47839 \pm 6266(84 \%)^{*}$
$61508 \pm 2279(108 \%)^{*}$

\section{LETO rats}

(c.p.m./mg protein)

$\begin{array}{cll}\text { Basal } & 56951 \pm 5436(100 \%) & 47154 \pm 6832(100 \%) \\ 2 & 66062 \pm 8544(116 \%) & 64600 \pm 7074(137 \%) \\ 5 & 80302 \pm 11390(141 \%) & 61302 \pm 7544(130 \%) \\ 10 & 47839 \pm 6266(84 \%)^{*} & 75446 \pm 8958(160 \%) \\ 20 & 61508 \pm 2279(108 \%)^{*} & 95249 \pm 8488(202 \%)\end{array}$

(b) Insulin-stimulated $\left[{ }^{3} \mathrm{H}\right]$ palmitate incorporation into diacylglycerol

$\begin{array}{clc}\text { Basal } & 67862 \pm 6413(100 \%) & 72967 \pm 6975(100 \%) \\ 2 & 83695 \pm 8144(123 \%) & 96351 \pm 10214(132 \%) \\ 5 & 72341 \pm 6787(106 \%) & 77344 \pm 9484(106 \%) \\ 10 & 87187 \pm 11334(128 \%) & 107993 \pm 10944(148 \%) \\ 20 & 87498 \pm 9502(129 \%)^{*} & 149586 \pm 8758(205 \%)\end{array}$

(c) diacylglycerol content

\begin{tabular}{|c|c|c|}
\hline & $\begin{array}{l}\text { OLETF rats } \\
\left({ }^{32} \mathrm{P} \text { c.p.m./mg protein) }\right.\end{array}$ & $\begin{array}{l}\text { LETO rats } \\
\left({ }^{32} \mathrm{P} \text { c.p.m./mg protein }\right)\end{array}$ \\
\hline \multicolumn{3}{|l|}{$\begin{array}{l}\text { Time } \\
(\min )\end{array}$} \\
\hline Basal & $10787 \pm 721(100 \%)$ & $10947 \pm 733(100 \%)$ \\
\hline 2 & $12498 \pm 1295(116 \%)^{*}$ & $21347 \pm 1533$ (195\%) \\
\hline 5 & $6793 \pm 1403(63 \%)$ & $10070 \pm 1642(92 \%)$ \\
\hline 10 & $12698 \pm 862(118 \%)$ & $16421 \pm 1203(150 \%)$ \\
\hline 20 & $16849 \pm 1511(156 \%)^{*}$ & $36674 \pm 2081(335 \%)$ \\
\hline
\end{tabular}

${ }^{*} P<0 \cdot 05-0 \cdot 01$ compared with LETO rats (Student's $t$-test).

(DETAPAC), and then incubated for $30 \mathrm{~min}$ at $25^{\circ} \mathrm{C}$ after the addition of $50 \mu \mathrm{l}$ solution II $(100 \mathrm{mM}$ imidazol$\mathrm{HCl}, \mathrm{pH} 6 \cdot 6,100 \mathrm{mM} \mathrm{NaCl}, 25 \mathrm{mM} \mathrm{MgCl}_{2}, 2 \mathrm{mM}$ EGTA), $20 \mu$ l solution III ( $2 \cdot 2 \mathrm{mM}$ dithiothreitol, $0 \cdot 1 \mathrm{mg} /$ $\mathrm{ml}$ DG kinase; Calbiochem Co., San Diego, CA, USA) and $10 \mu \mathrm{l}$ solution IV $\left(1 \mathrm{mM}\left[\gamma-{ }^{32} \mathrm{P}\right] \mathrm{ATP}, 100 \mathrm{mM}\right.$ imidazol and $1 \mathrm{mM}$ DETAPAC). The reaction was stopped with $2 \mathrm{ml}$ chloroform/methanol (2:1) and then washed twice with chloroform and $1 \mathrm{M} \mathrm{NaCl}$. Aliquots were analyzed by TLC on silica gel plates, developed in chloroform/methanol/acetic acid (65:15:5) and products detected by autography to obtain phosphatidic acid formation by DG kinase.

\section{PKC $m R N A$ experiment}

Total RNA was prepared using ISOGEN (Nippon Gene Inc., Toyama, Japan). In general $1-2 \mathrm{ml}$ of packed adipocytes were lyzed in $0.5 \mathrm{ml}$ ISOGEN solution,

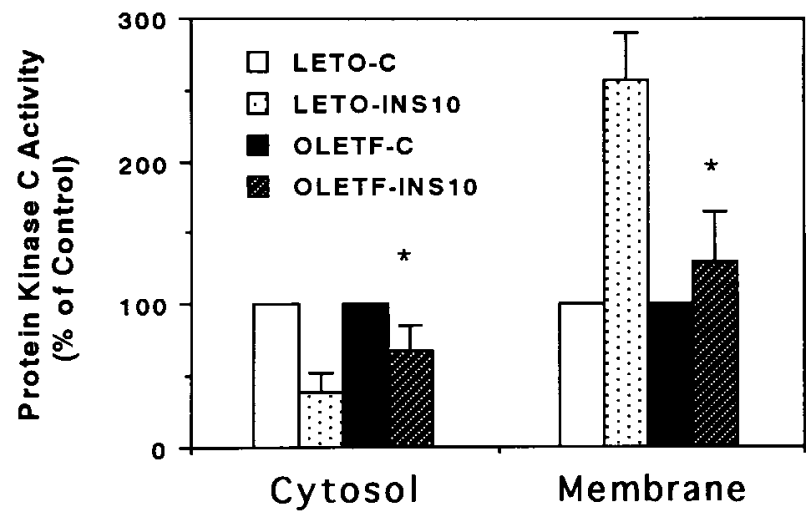

Figure 3 Insulin-induced translocation of Mono Q column-purified PKC activity in adipocytes of OLETF and LETO rats at 18 weeks of age. Cytosolic and membrane-associated PKC activities were measured as indicated in Materials and Methods. PKC activity was expressed as the percentage of unstimulated PKC activity (control: C). Values are means \pm S.E. of three separate experiments. ${ }^{*} P<0 \cdot 05$ vs LETO-INS 10 (Student's $t$-test). 


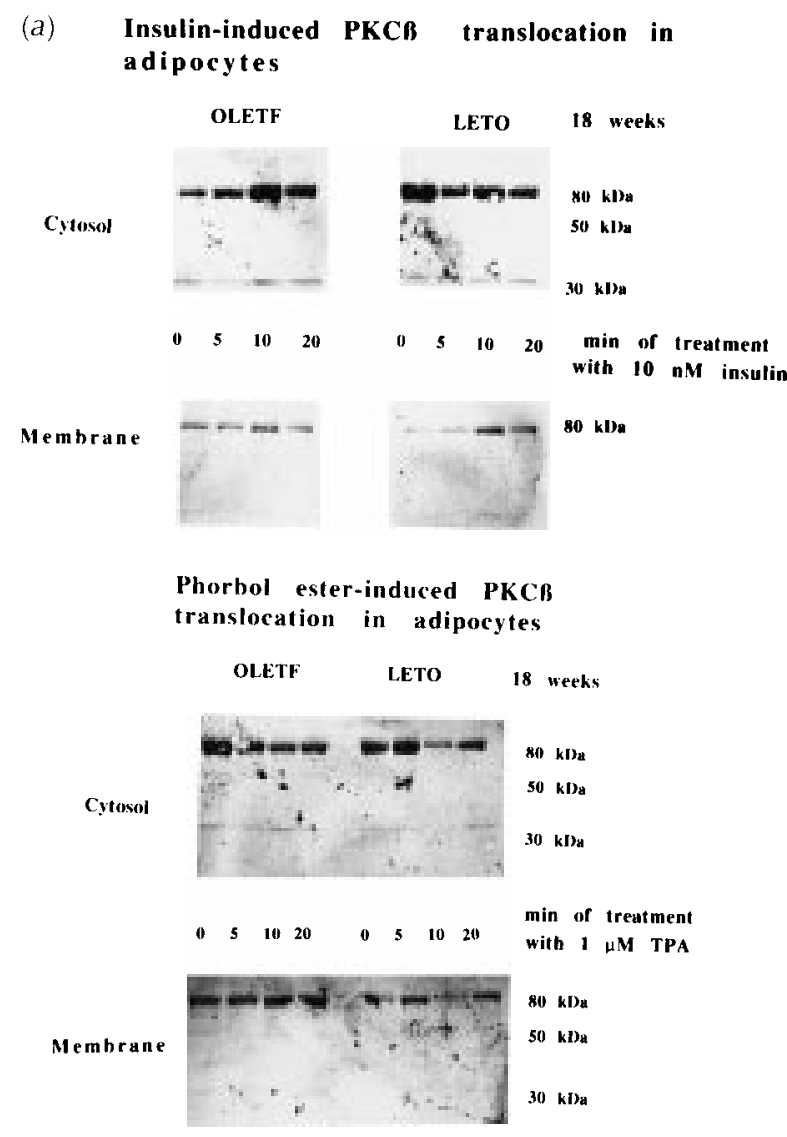

(b)

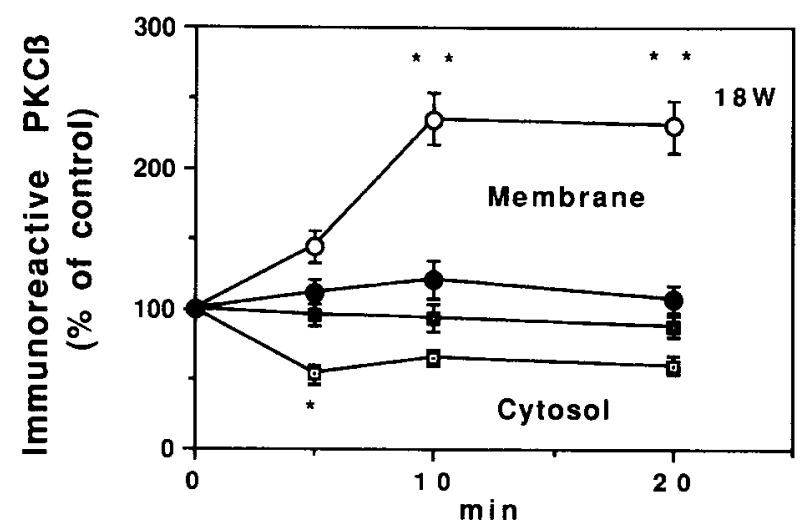

TPA-induced PKCB changes

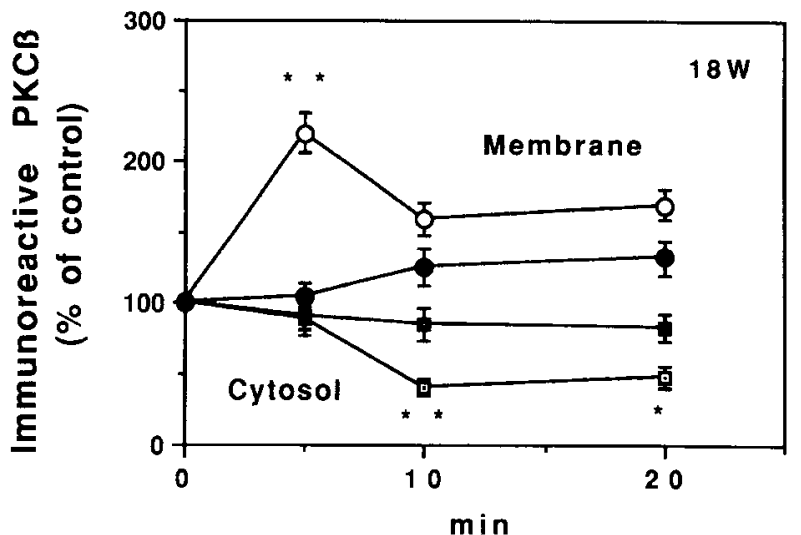

Figure 4 Insulin- and TPA-induced redistribution of PKC $\beta$ immunoreactivity in adipocytes of OLETF and LETO rats at 18 weeks of age. Cytosolic and membrane-associated proteins $(30 \mu \mathrm{g})$ were subjected to SDS-PAGE, transferred, and analyzed as indicated in Materials and Methods. (a) Representative experiment. (b) Densitometric data of PKC $\beta$ immunoreactivity in adipocytes of OLETF $(\boldsymbol{\bullet}, \boldsymbol{\square})$ and LETO $(\bigcirc, \square)$ rats. Cytosolic protein (squares), membrane-associated protein (circles). Results are means \pm S.E. of three experiments. ${ }^{* *} P<0 \cdot 01$, $* P<0 \cdot 05$ vs OLETF rats.

followed by chloroform extraction and isopropanol/ ethanol precipitation. First strand cDNA synthesis was performed according to the method of Frohman et al. (1988). At the end of the incubation period, samples were diluted with $80 \mu \mathrm{l}$ Tris-EDTA buffer $(10 \mathrm{mM}$ Tris-HCl, $1 \mathrm{mM}$ EDTA, $\mathrm{pH} 7 \cdot 4)$. Aliquots of $10 \mu \mathrm{l}$ of first strand cDNA were mixed with $40 \mu \mathrm{l}$ PCR mix (Takara Shuzo Co., Tokyo, Japan). Primers specific for the different PKC isozymes were designed based on reported sequences from the Gene Bank data base as indicated in Table 1. The location of the primers in the cDNA sequences was selected in such a way that they would target the specific region (Ono et al. 1989). Hypoxanthine phosphoribosyl- transferase (Hprt) mRNA level was used as a control and was not affected by insulin or phorbol ester. PCR amplification was carried out using a Perkin-Elmer thermal cycle set for 30 to 40 cycles. The temperatures used for PCR were: denaturing $94^{\circ} \mathrm{C}, 1 \mathrm{~min}$; annealing $55^{\circ} \mathrm{C}$, $2 \mathrm{~min}$; primer extension $72{ }^{\circ} \mathrm{C}, 3 \mathrm{~min}$. PCR fragments were analyzed by electrophoresis on $1.5 \%$ agarose gel, and DNA was visualized by ethidium bromide staining.

\section{PI 3-kinase assay}

Isolated adipocytes were treated with or without insulin $(10 \mathrm{nM})$ for $0,1,5,10$ and $60 \mathrm{~min}$ at $37^{\circ} \mathrm{C}$, lyzed in

Figure 5 (a) Immunoblot analysis of insulin-induced translocation of PKC $\beta I, \beta I I, \varepsilon$ and $\zeta$ in adipocytes of OLETF and LETO rats. Cytosolic and membrane-associated proteins $(30 \mu \mathrm{g})$ were subjected to SDS-PAGE, transferred, and analyzed as indicated in Materials and Methods. (b) Densitometric data of PKC isoforms in adipocytes of $\operatorname{OLETF}(\boldsymbol{\bullet}, \mathbf{0})$ and $\operatorname{LETO}(\bigcirc, \square)$ rats. Cytosolic protein (squares), membraneassociated protein (circles). Results are means \pm S.E. of three experiments. ${ }^{*} P<0 \cdot 01,{ }^{\star} P<0 \cdot 05$ vs OLETF rats. 
(a) Immunoblot analysis of $\mathrm{PKCBI}$ in rat adipocytes

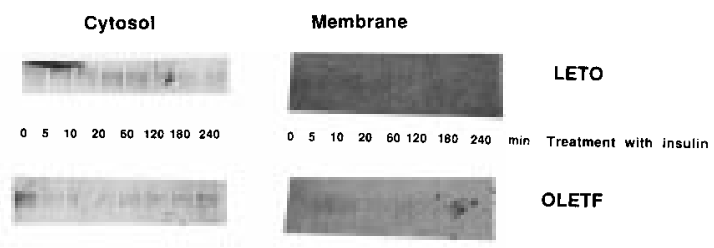

Immunoblot analysis of $\mathrm{PKCBII}$ in rat adipocytes

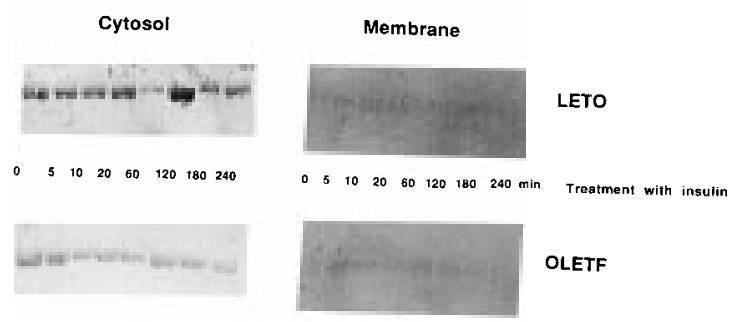

Immunoblot analysis of $\mathrm{PKC} \varepsilon$ in rat adipocytes
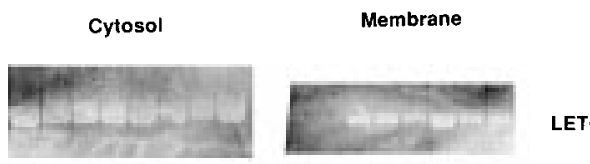

D 5 10206012018024

O $5102060 \quad 120180240 \mathrm{~min}$

Treatment with insulin
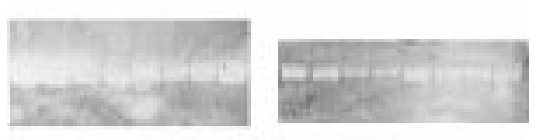

OLETF

Immunoblot analysis of $\mathrm{PKC} \zeta$ in rat adipocytes

Cytosol

Membrane
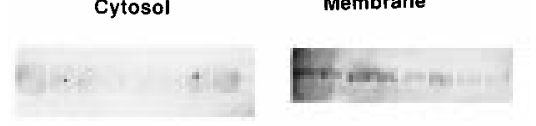

LETO

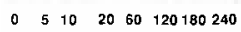

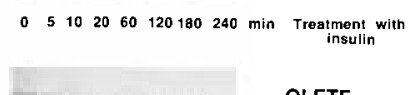

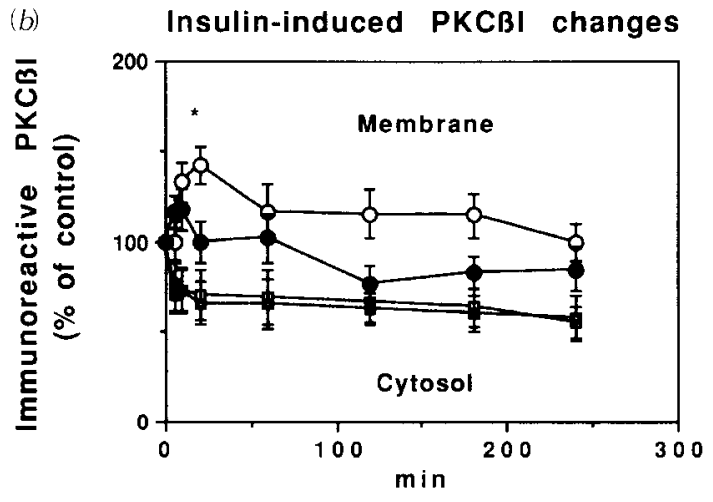

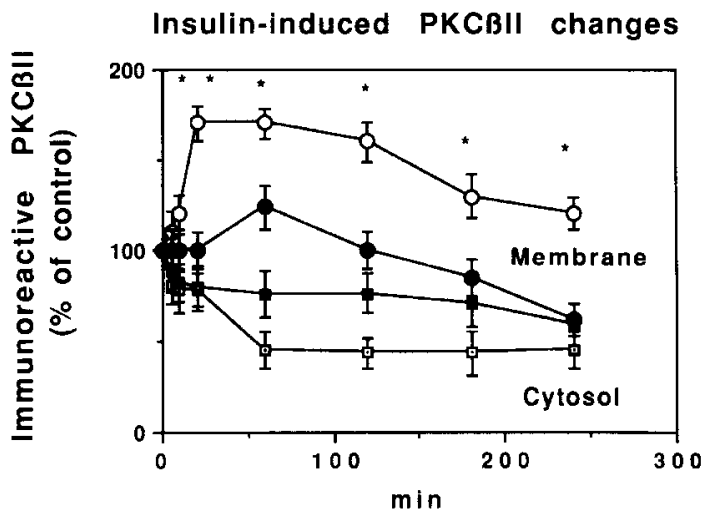

Insulin-induced PKC $\varepsilon$ changes

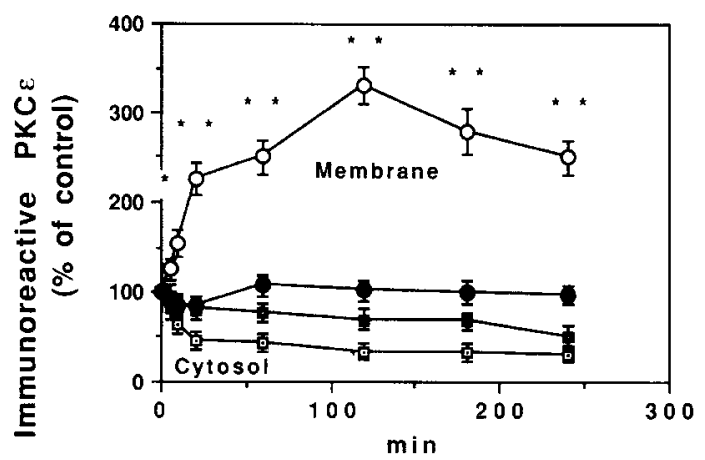

Insulin-induced PKC $\zeta$ Changes

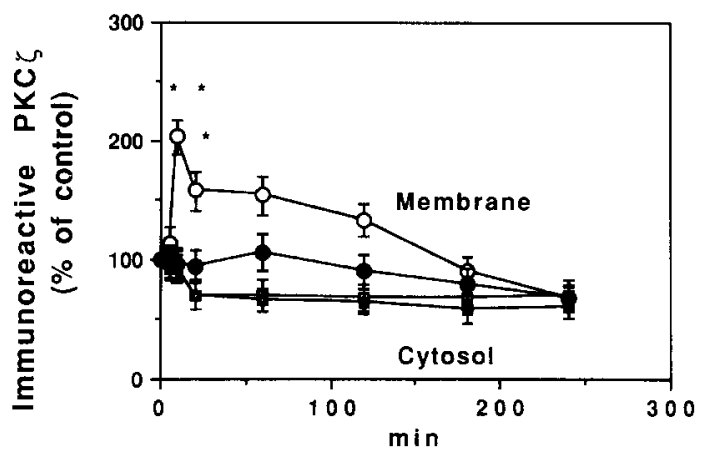


buffer containing 1\% (vol/vol) Nonidet P-40 (Hayashi et al. 1992), and immunoprecipitated with an antiphosphotyrosine antibody (Kanai et al. 1993) and protein A-agarose. The immunoprecipitates were washed and subjected to the PI 3-kinase assay as described (Hayashi et al. 1992). Briefly, cells were treated with $10 \mathrm{nM}$ insulin for the indicated periods and lyzed in the buffer (20 mM Tris- $\mathrm{HCl}, \mathrm{pH} \mathrm{7.4,} \mathrm{1 \%} \mathrm{Nonidet} \mathrm{P-40,} \mathrm{0.5} \mathrm{mM}$ EDTA, 5\% glycerol, $1 \mathrm{mM}$ orthovanadate, and $20 \mu \mathrm{M}$ p-amidinophenylmethanesulfonyl fluoride hydrochloride) and sonicated. The homogenates were centrifuged at 15000 r.p.m. for $20 \mathrm{~min}$, and the indicated supernatants were incubated with $4 \mu \mathrm{g}$ anti-phosphotyrosine antibody for $2 \mathrm{~h}$ at $4{ }^{\circ} \mathrm{C}$. The immunocomplexes were precipitated with $40 \mu \mathrm{l}$ protein A-agarose and washed twice. The immunoprecipitates were subjected to the PI kinase assay in a $50-\mu$ reaction mixture containing $20 \mathrm{mM}$ Tris $-\mathrm{HCl}$, $\mathrm{pH} 7 \cdot 4,100 \mathrm{mM} \mathrm{NaCl}, 10 \mathrm{mM} \mathrm{MgCl} 2,0 \cdot 5 \mathrm{mM}$ EGTA, $100 \mu \mathrm{M} \mathrm{PI}, 100 \mu \mathrm{M}$ phosphatidylserine, and $10 \mu \mathrm{M}$ $\left[\gamma-{ }^{32} \mathrm{P}\right]$ ATP $(0 \cdot 1 \mu \mathrm{Ci} / \mu \mathrm{l})$. After $10 \mathrm{~min}$ at $30^{\circ} \mathrm{C}$ the reaction was stopped by adding $200 \mu \mathrm{l} 1 \mathrm{M} \mathrm{HCl}$ and $80 \mu \mathrm{l}$ chloroform/methanol $(1: 1, \mathrm{vol} / \mathrm{vol})$. A $30 \mu \mathrm{l}$ portion of the lower layer was spotted onto a silica gel 60 plate (Merck) and developed in chloroform/methanol/25\% $\mathrm{NH}_{4} \mathrm{Cl} /$ water $(43: 38: 5: 7, \mathrm{vol} / \mathrm{vol})$. The radioactive PI phosphate spot was detected by autoradiography, scraped from the plate and quantified by liquid scintillation counting.

\section{Immunoblot}

Immunoprecipitates with the anti-phosphotyrosine antibody were separated by SDS-PAGE and transferred onto nitrocellulose paper. The paper was blocked with 3\% gelatin TBS and incubated with the anti-p85 PI 3-kinase antibody (1:1000 dilution) for 4-5 days. Protein bands were located using the Enhanced ChemiLuminescence (ECL) system.

Statistical comparisons were performed by standard Student's t-test for planned paired comparisons where appropriate. Unless otherwise stated, all data are expressed as means \pm S.E.

\section{Results}

Clinical profiles of OLETF and LETO rats from 8 to 30 weeks of age

Body weight, fed plasma glucose and immunoreactive insulin (IRI) levels are shown in Table 2. Up to 12 weeks, there was no significant difference in any of these values, whereas after 18 weeks significant increases in plasma glucose and IRI levels were observed in OLETF rats compared with LETO rats.

Insulin- or phorbol ester-stimulated glucose uptake in adipocytes of OLETF and LETO rats

Insulin (10 nM)-stimulated $\left[{ }^{3} \mathrm{H}\right] 2-D O G$ uptake in adipocytes of OLETF rats at 12 weeks of age was slightly lower compared with that in adipocytes of LETO rats. A phorbol ester, TPA-stimulated $\left[{ }^{3} \mathrm{H}\right] 2-\mathrm{DOG}$ uptake in adipocytes of OLETF rats at 12 weeks of age was also slightly decreased compared with that in adipocytes of LETO rats (data not shown).

At 18 weeks of age, $10 \mathrm{nM}$ insulin- or $1 \mu \mathrm{M}$ TPAstimulated $\left[{ }^{3} \mathrm{H}\right] 2-\mathrm{DOG}$ uptake in adipocytes of OLETF rats was apparently decreased compared with that of LETO rats (insulin-stimulated $\left[{ }^{3} \mathrm{H}\right] 2-\mathrm{DOG}$ uptake: OLETF $72 \cdot 7 \pm 6.6 \mathrm{pmol} / \mathrm{mg}$ protein vs LETO $164.3 \pm 8.8 \mathrm{pmol} /$ mg protein, $P<0 \cdot 01$; TPA-stimulated $\left[{ }^{3} \mathrm{H}\right] 2-\mathrm{DOG}$ uptake: OLETF $40.5 \pm 4.9 \mathrm{pmol} / \mathrm{mg}$ protein vs LETO $82.5 \pm$ $5.8 \mathrm{pmol} / \mathrm{mg}$ protein, $P<0 \cdot 01$; unstimulated $\left[{ }^{3} \mathrm{H}\right] 2-\mathrm{DOG}$ uptake: OLETF $31.7 \pm 4.4 \mathrm{pmol} / \mathrm{mg}$ protein, LETO $38.6 \pm 7 \cdot 6 \mathrm{pmol} / \mathrm{mg}$ protein) as indicated in Fig. 1.

Insulin-specific binding to insulin receptor and autophosphorylation of insulin receptor in adipocytes of OLETF and LETO rats

After 18 weeks of age, ${ }^{125}$ I-insulin binding activity and $95 \mathrm{kDa}$ tyrosine kinase activity of the insulin receptor $\beta$ subunit in adipocytes of OLETF rats was not significantly different from those of LETO rats (Fig. 2). Densitometric analysis of $95 \mathrm{kDa}$ autophosphorylation (right panel in Fig. 2) in adipocytes of OLETF rats was not changed compared with those of LETO rats (upper left panel in Fig. 2).

Insulin-induced $\left.{ }^{3} \mathrm{H}\right]$ diacylglycerol production and diacylglycerol content in adipocytes of OLETF and LETO rats

After stimulation with $10 \mathrm{nM}$ insulin, $\left[{ }^{3} \mathrm{H}\right] \mathrm{DG}$ production was increased by $5 \mathrm{~min}$, then decreased to the unstimulated level, and increased by $20 \mathrm{~min}$ in adipocytes of OLETF and LETO rats at 12 weeks of age (data not shown). On the other hand, $\left[{ }^{3} \mathrm{H}\right] \mathrm{glyc}$ cerol incorporation into DG in adipocytes of OLETF rats at 18 weeks of age

Figure 6 Expression of (a) PKC $\beta \mathrm{I}, \beta \mathrm{II}, \varepsilon, \zeta$ isoforms and (b) Hprt in adipocytes of OLETF and LETO rats. Total RNA (0.5 $\mu \mathrm{g})$ from isolated adipocytes was reverse-transcribed and aliquots of cDNA pools were obtained after the reaction was terminated by the addition of $0 \cdot 5 \mathrm{ml}$ ISOGEN to insulin-stimulated packed adipocytes $(1 \mathrm{ml})$ at each of the indicated times. Agarose gel electrophoresis of the PCR products generated after 35 cycles of amplification of rat adipocytes cDNA using the pairs of oligonucleotide primers was carried out as indicated in Materials and Methods. (c) Densitometric data of PKC isoform mRNA in adipocytes of OLETF ( ) and LETO (O) rats. Results are means \pm S.E. of three separate experiments. ${ }^{*} P<0 \cdot 01,{ }^{*} P<0 \cdot 05$ vs OLETF rats. 
(a) Insulin-induced PKC BI m-RNA change in rat adipocytes

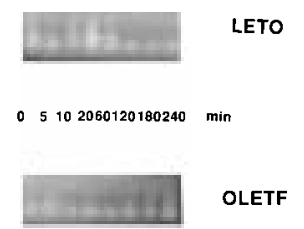

Insulin-induced PKC BII m-RNA change in rat adipocytes

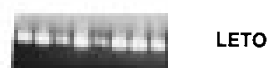

$05102060120180240 \quad \min$

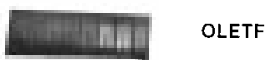

Insulin-induced PKC $\varepsilon$ m-RNA changes in adipocytes of OLETF and LETO rats

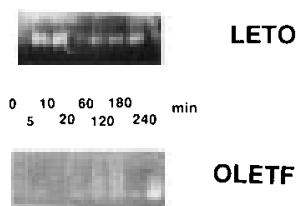

Insulin-induced PKC $\zeta$ m-RNA change in ral adipocytes

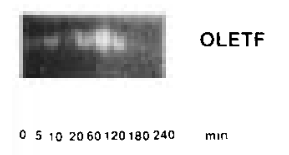

XVI:W LETO

(b)

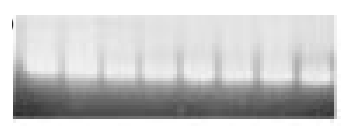

LETO

$05102060120180240 \quad \min$

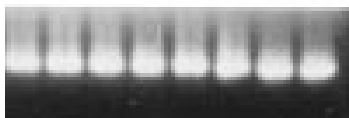

OLETF (c)

Insulin-induced PKCBI m-RNA change

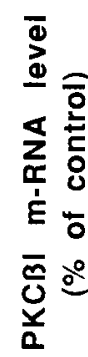

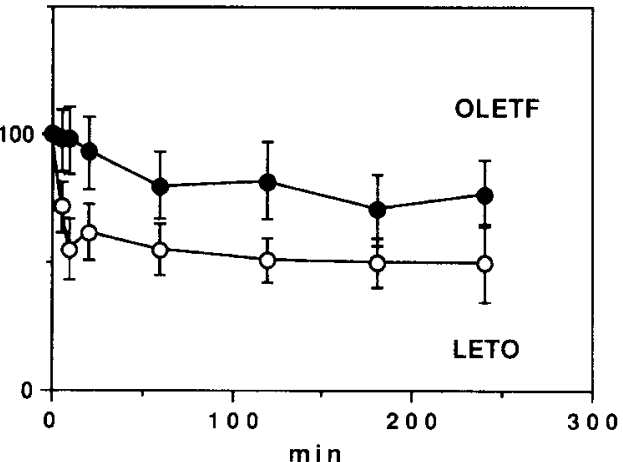

Insulin-induced PKCBII m-RNA change

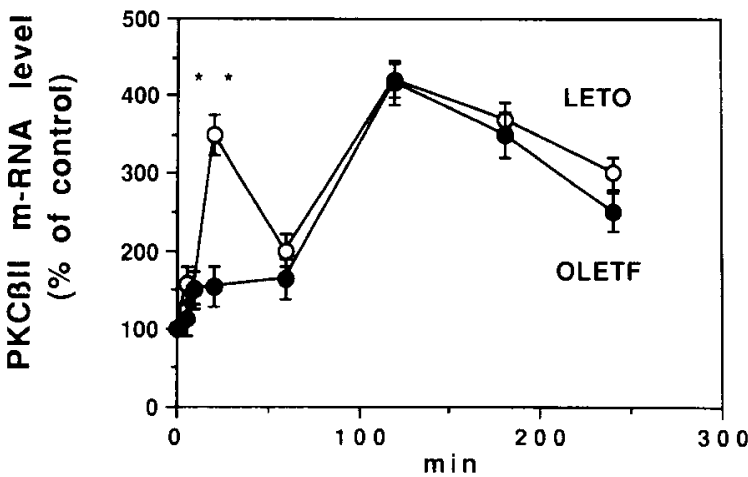

Insulin-induced PKC $\varepsilon$ m-RNA change

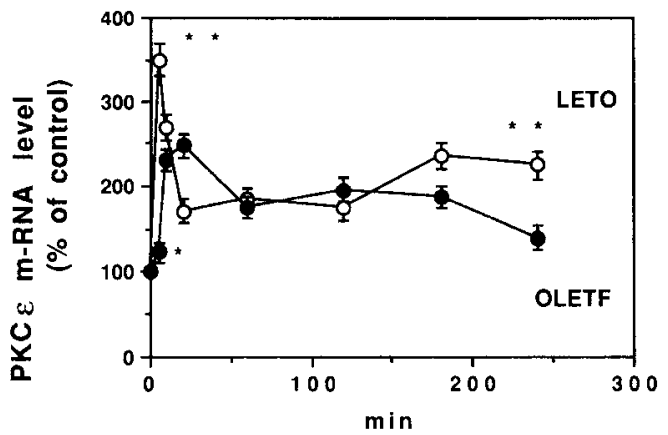

Insulin-induced PKC $\zeta$ m-RNA change

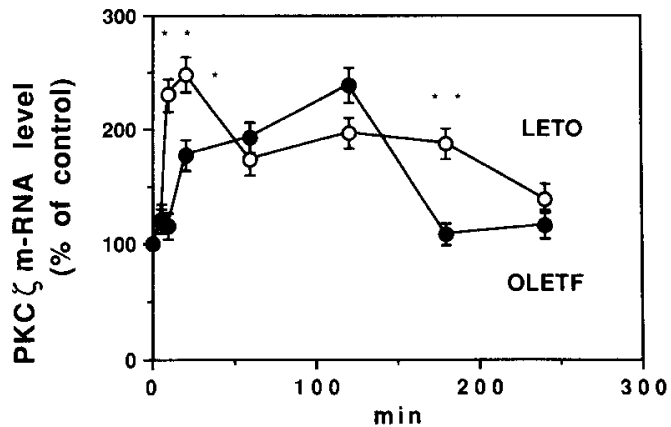

Journal of Endocrinology (1998) 156, 1-13 
was not similar to that in adipocytes of LETO rats. At 10 and 20 min post stimulation with $10 \mathrm{nM}$ insulin the second peak of DG generation was decreased in adipocytes of OLETF rats at 18 weeks of age $(P<0.01$ vs values in LETO) (Table 3a). Insulin-induced $\left[{ }^{3} \mathrm{H}\right]$ palmitic acid incorporation into DG and DG content in adipocytes of OLETF rats at 18 weeks of age were also decreased compared with those of LETO rats (Table 3b). Diacylglycerol content was measured by the DG-kinase method as shown in Materials and Methods. Insulin-induced DG content in adipocytes of 18-week-old OLETF rats at 2 and 20 min was significantly decreased compared with that of LETO rats (Table 3c).

Insulin- or TPA-induced protein kinase C (PKC) translocation in adipocytes of OLETF and LETO rats

At 12 weeks of age the cytosolic PKC activity was decreased to $38 \%$ of the unstimulated level (control) and membrane-associated PKC activity was increased to $198 \%$ of control in adipocytes of LETO rats during treatment with $10 \mathrm{nM}$ insulin, which was not different from that of OLETF rats. However, insulin-induced translocation of PKC activity in adipocytes of 18-week-old OLETF rats was markedly reduced compared with that of LETO rats (cytosolic PKC activity during treatment with $10 \mathrm{nM}$ insulin: LETO $39 \pm 14 \%$ vs OLETF $68 \pm 18 \%, P<0 \cdot 05$; membrane-associated PKC activity during treatment with $10 \mathrm{nM}$ insulin: LETO $258 \pm 32$ vs OLETF $130 \pm 35 \%$, $P<0.05)$ (Fig. 3).

Immunoreactive analysis of $\mathrm{PKC} \beta$ indicated that insulin-induced PKC $\beta$ translocation in adipocytes of OLETF rats was slightly smaller than that of LETO rats at 12 weeks of age. Densitometric analysis of changes in PKC $\beta$ immunoreactivity in adipocytes of OLETF rats was similar to that of LETO rats during treatment with $10 \mathrm{nM}$ insulin. TPA-induced PKC translocation was not different in adipocytes of OLETF and LETO rats at 12 weeks of age (data not shown). At 18 weeks of age, membraneassociated PKC $\beta$ immunoreactivity in adipocytes of OLETF rats was slightly higher than that of LETO rats before insulin stimulation, but insulin-stimulated increases of membrane-associated and decreases of cytosolic PKC $\beta$ immunoreactivities in adipocytes of OLETF rats were smaller compared with LETO rats as shown in Fig. $4 a$. PKC $\beta$ immunoreactivity in adipocytes of OLETF rats was

Figure 7 Insulin- and TPA-stimulated (a) PI 3-kinase activity and (b) p85 subunit of PI 3-kinase immunoreactivity in adipocytes of OLETF and LETO rats. PI 3-kinase activity and p85 subunit of PI 3-kinase immunoreactivity were measured as described in Materials and Methods. (c) Densitometric data of PI 3-kinase activity and p85 subunit of PI 3-kinase immunoreactivity in adipocytes of OLETF (solid bars) and LETO (open bars) rats. Results are means \pm S.E. of three separate experiments. ${ }^{*} P<0 \cdot 01$, ${ }^{*} P<0.05$ vs OLETF rats.

(a)

Insulin- and TPA-induced PI 3-kinase activation in rat adipocytes

INS

LETO

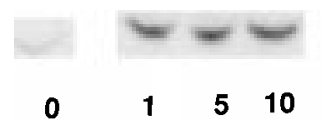

0$$
510
$$

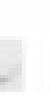

(b) Immunoblot analysis of $\mathbf{P I}$ 3-kinase (p85) in
rat adipocytes
LETO

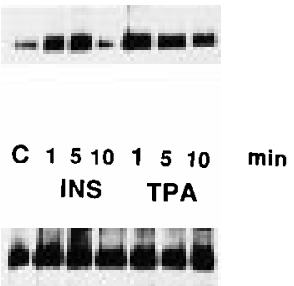

OLETF
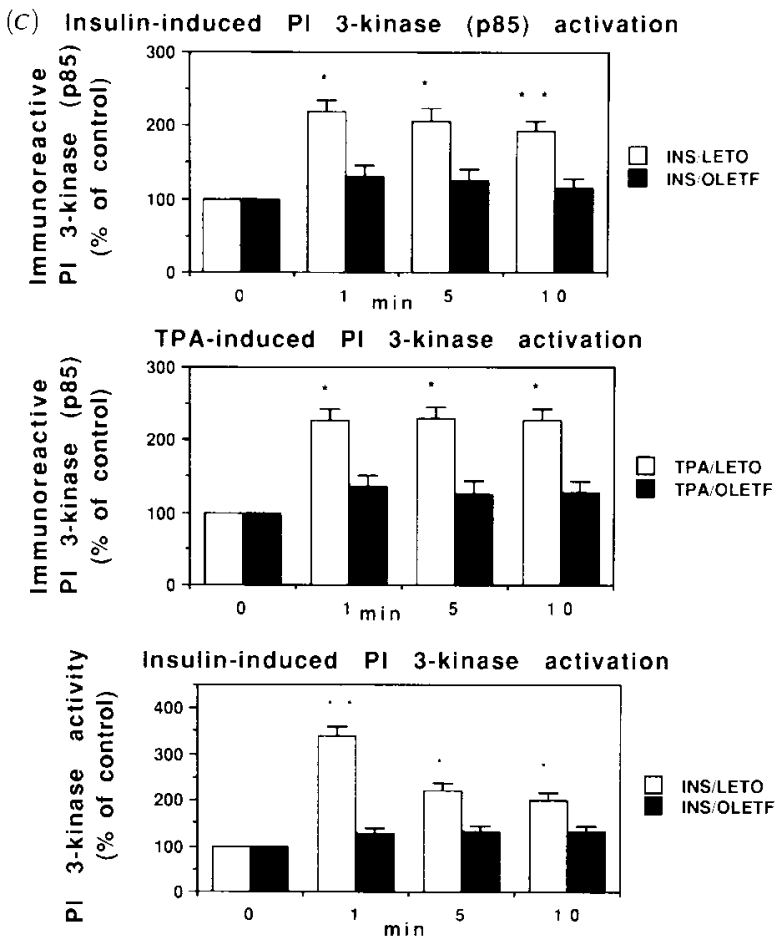

TPA-induced PI 3-kinase activation

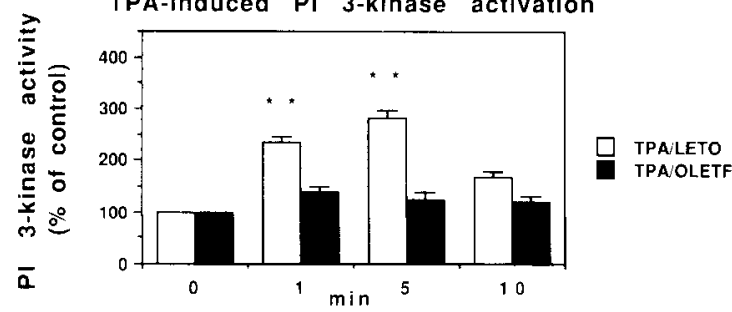


also smaller than that of LETO rats by densitometric analysis (Fig. 4b) (cytosolic fraction in adipocytes of OLETF vs LETO rats: 0 min $100 \%, 5$ min $96 \pm 8 \%$ vs $53 \pm 7 \%, P<0 \cdot 02,10 \mathrm{~min} 94 \pm 9 \%$ vs $65 \pm 6 \%, 20 \mathrm{~min}$ $89 \pm 8 \%$ vs $60 \pm 7 \%$; membrane fraction in OLETF vs LETO adipocytes: $0 \mathrm{~min} 100 \%, 5 \mathrm{~min} 111 \pm 11 \%$ vs $144 \pm 12 \%, 10 \mathrm{~min} 121 \pm 13 \%$ vs $235 \pm 18 \%, P<0 \cdot 01$, $20 \mathrm{~min} 108 \pm 10 \%$ vs $230 \pm 19 \%, P<0 \cdot 01)$. These results indicated that insulin-induced PKC $\beta$ translocation in adipocytes of OLETF rats was markedly decreased compared with that of LETO rats. TPA-induced PKC $\beta$ translocation in adipocytes of OLETF rats was also decreased as indicated in Fig. 4b. Densitometric analysis of PKC $\beta$ immunoreactivity in adipocytes of OLETF and LETO rats revealed significantly decreased TPA-induced PKC $\beta$ translocation in adipocytes of OLETF rats (cytosolic fraction in adipocytes of OLETF vs LETO rats: $0 \mathrm{~min}$ $100 \%, 5 \min 91 \pm 9 \%$ vs $88 \pm 8 \%, 10 \min 85 \pm 7 \%$ vs $40 \pm 6 \%, P<0 \cdot 01,20 \mathrm{~min} 83 \pm 9 \%$ vs $48 \pm 7 \%, P<0 \cdot 05$; membrane fraction in adipocytes of OLETF vs LETO rats: $0 \mathrm{~min} 100 \%, 5 \mathrm{~min} 104 \pm 9 \%$ vs $220 \pm 15 \%, P<0 \cdot 01$, $10 \min 125 \pm 13 \%$ vs $160 \pm 12 \%, 20 \min 132 \pm 12 \%$ vs $170 \pm 10 \%)$.

Immunoblot analysis of insulin-induced translocation of protein kinase $C \beta I, \beta I I, \varepsilon$ and $\zeta$ in adipocytes of OLETF and LETO rats

Analysis of PKC $\beta \mathrm{I}, \beta \mathrm{II}, \varepsilon$ and $\zeta$ isoforms in adipocytes of OLETF and LETO rats at 18 weeks of age by immunoblot indicated weak insulin-induced translocations of PKC $\beta I$, $\beta \mathrm{II}, \varepsilon$ and $\zeta$ from cytosol to membrane in OLETF rats compared with those in LETO rats; increases of each membrane-associated PKC isoform by insulin in adipocytes of OLETF rats were smaller than those of LETO rats (Fig. $5 a$ ). Densitometric analyses of PKC $\beta \mathrm{I}, \beta \mathrm{II}, \varepsilon$ and $\zeta$ isoforms showed that membrane-associated PKC $\beta \mathrm{I}$ at $20 \mathrm{~min}, \mathrm{PKC} \varepsilon$ at 10 and $20 \mathrm{~min}$ and PKC $\beta \mathrm{II}$ and PKC $\varepsilon$ at 10,20,60,120,180 and $240 \mathrm{~min}$ after treatment with insulin in adipocytes of OLETF rats were significantly higher than those of LETO rats, but insulin-induced alterations of cytosolic PKC $\beta \mathrm{I}, \beta \mathrm{II}, \varepsilon$ and $\zeta$ in adipocytes of OLETF rats were not significantly different from those of LETO rats as shown in Fig. $5 b$.

Alterations of insulin-induced PKC $B I, \beta I I, \varepsilon$, and $\zeta m R N A$ levels in adipocytes of OLETF and LETO rats

Basal levels of insulin-induced PKC $\beta \mathrm{I}, \beta \mathrm{II}, \varepsilon$, and $\zeta$ mRNA in adipocytes of OLETF rats were lower than those in LETO rats and, moreover, alterations of each insulin-regulated PKC isoform in adipocytes of OLETF rats were slower than those in LETO rats (Fig. 6a). Densitometric analyses of PKC isoform mRNA showed that the insulin-regulated decrease in PKC $\beta I$ mRNA in OLETF rats was not significantly different from that in LETO rats, while the insulin-regulated increases in PKC $\beta I I, \varepsilon$, and $\zeta$ mRNA in OLETF rats were slower than those in LETO rats. The insulin-mediated first peak of PKC $\beta I \mathrm{II}$ mRA at $10 \mathrm{~min}$ was diminished in OLETF rats. Insulin-mediated peaks of PKC $\varepsilon$ and $\zeta$ mRNA in OLETF rats were slower than those in LETO rats (Fig. $6 c$ ).

Alterations of insulin- and TPA-induced PI 3-kinase activity and $p 85$ subunit of PI 3-kinase immunoreactivity in adipocytes of OLETF and LETO rats

Insulin- and TPA-induced increases in PI 3-kinase activity and p85 subunit of PI 3-kinase immunoreactivity in adipocytes of OLETF rats were suppressed compared with those of LETO rats (Fig. 7a,b). Densitometric analyses of the p85 subunit of PI 3-kinase (upper 2 panels) and PI 3-kinase activity (lower 2 panels) showed that insulin- and TPA-induced increases in p85 immunoreactivity and PI 3-kinase activity in LETO rats were significantly higher than those in OLETF rats as shown in Fig. $7 c$.

\section{Discussion}

Previous reports of impaired PKC activity from obese Zucker rats heart and liver and a decrease in the responsiveness of glucose uptake to insulin and TPA in Zucker and old-obese rats (Ishizuka et al. 1993, Van de Werve et al. 1987) prompted us to investigate PKC $\beta$ immunoreactivity and PKC activity in OLETF rats.

Insulin resistance occurs in adipocytes and skeletal muscle in OLETF rats (Kawano et al. 1992). Insulin binding is also decreased in obese Zucker rats (King et al. 1992). Several investigators have reported that glucose transporter levels are maintained in insulin-resistant soleus muscle (Crettaz et al. 1980, Friedman et al. 1990, King et al. 1992), but the translocation of glucose transporter depends on a number of cellular factors, including PKC, as reported in adipocytes and soleus muscle (ObermaierKusser et al. 1989, Cleland et al. 1990). As we have shown previously, PKC activity is lower in soleus muscle of the old-obese rats (Ishizuka et al. 1993) and Zucker obese rats (Cooper et al. 1993). However, since PKC activity did not exhibit much difference in adipocytes (Ishizuka et al. 1993), we could not attribute the decreased glucose transport activity simply to the decreased basal PKC activity in adipocytes. Recently, insulin binding, receptor autophosphorylation and the tyrosine kinase activity of partially purified insulin receptor from skeletal muscles of OLETF rats have been shown not to differ from those of LETO rats (Sato et al. 1994). In the present study, we have shown reduced activation and translocation of PKC $\beta$ by insulin and TPA in adipocytes of OLETF rats.

There are several explanations for the decreases in PKC activation and translocation by insulin and TPA in OLETF rat adipocytes. First, the decreased PKC activation 
resulting from decreased generation of $\mathrm{DG}$ by insulin could decrease the translocation of PKC. In fact, as indicated in Fig. 3, insulin-induced DG generation, especially the second peak of DG, was reduced and subsequently the insulin-provoked PKC translocation was also decreased.

Secondly, the synthesis of new PKC is decreased due to defective translation or decreased transcription of $\mathrm{PKC}$ gene or a genetic mutation yielding an inactive or altered PKC enzyme. In either case, a decreased activation of PKC may explain alterations in glucose transport activity which result in insulin resistance in OLETF rats. In previous papers, we have demonstrated in rat adipocytes that down-regulation of PKC by chronic treatment by phorbol esters or antisense oligonucleotides directed against PKC $\alpha$ and $\beta$ suppressed insulin-stimulated glucose uptake (Ishizuka et al. 1991, Cooper et al. 1992, Farese et al. 1992). In adipocytes of OLETF rats at 18 weeks of age, high glucose and hyperinsulinemia, as shown in Table 2, may result in down-regulation of PKC mRNA, especially the PKC $\beta I$ is isoform with subsequently reduced insulin-induced activation of PKC. In addition to decreased basal PKC $\beta I I$ mRNA expression, insulinregulated alterations of $\mathrm{PKC}$ isoform mRNA levels in adipocytes of OLETF rats were slower than those of LETO rats as indicated in Fig. 6. Recently, it has been reported that insulin regulates alternative splicing of PKC $\beta$, and that switching PKC $\beta$ I to PKC $\beta$ II may provoke long activation of protein kinase $\mathrm{C}$ because of down-regulation-resistant PKC $\beta I I$ (Chalfant et al. 1995). Thus, delayed and weak alternative splicing of PKC $\beta$ and alteration of $\mathrm{PKC}$ isoforms may contribute to weak activation of $\mathrm{PKC}$ isoforms, and subsequently cause diminished glucose uptake in adipocytes of OLETF rats.

Activation of insulin-induced insulin-receptor substrate-1 (IRS-1) and PI 3-kinase by insulin or TPA was also examined. Although basal p85 subunit of PI 3-kinase immunoreactivity in adipocytes of OLETF rats was slightly higher than that in LETO rats, insulin-stimulated PI 3-kinase activity in adipocytes of OLETF rats was decreased compared with that in adipocytes of LETO rats. Unexpectedly, phorbol ester-stimulated PI 3-kinase activation was observed in adipocytes of OLETF and LETO rats. Interestingly, like insulin-stimulated activity, TPA-stimulated PI 3-kinase activity was also decreased in adipocytes of OLETF rats compared with those of LETO rats. It has been reported that PI 3-kinase activation by PKC stimulation could be observed in human platelets (King et al. 1991). Accordingly, phorbol ester may phosphorylate pleckstrin homology which is contained in IRS-1 (Voliovitch et al. 1995), and subsequently PI 3-kinase activity may be provoked through IRS-1 phosphorylation of pleckstrin homology. Finally, weak PKC signaling may cause decreased PI 3-kinase activation and a subsequent insulin-induced decreased metabolic effect.
In summary, hyperglycemia and/or hyperinsulinemia activate and eventually down-regulate PKC, and suppress activation of PKC due to a defective response of insulininduced DG generation. This decreased PKC activation may induce the deterioration of insulin-induced glucose uptake in rat adipocytes.

Further studies will enable us to determine whether the decreased PKC activation is the result of a genetic or acquired defect in PKC gene expression, which results in insulin resistance in NIDDM.

\section{References}

Cantley LC, Auger KR, Carpenter C, Duckworth B, Graziani A, Kapeller R \& Soltoff 1991 Oncogenes and signal transduction. Cell 64 281-302.

Carpenter CL \& Cantley LC 1990 Perspectives in biochemistry: phosphoinositide kinases. Biochemistry 29 11147-11156.

Chalfant CE, Mischak H, Watson JE, Winkler BC, Goodnight J, Cooper DR \& Farese RV 1995 Regulation of alternative splicing of protein kinase $C \beta$ by insulin. Journal of Biological Chemistry 270 13326-13332.

Cleland PJF, Abel KC, Rattigan S \& Clark MG 1990 Long term treatment of isolated rat soleus muscle with phorbol ester leads to loss of contraction-induced glucose transport. Biochemical Journal $\mathbf{2 6 7}$ 659-663.

Cooper DR, Watson JE, Hernandez H, Yu B, Standaert ML, Ways DK, Arnold TT, Ishizuka T \& Farese RV 1992 Direct evidence for protein kinase $\mathrm{C}$ involvement in insulin-stimulated hexose uptake. Biochemical and Biophysical Research Communications 188 142-148.

Cooper DR, Watson JE \& Dao ML 1993 Decreased expression of protein kinase-C, $\beta$, and $\varepsilon$ in soleus muscle of Zucker obese $(f a / f a)$ rats. Endocrinology 133 2241-2247.

Crettaz M, Prentki M, Zaninetti D \& Jeanrenaud B 1980 Insulin resistance in soleus muscle from obese Zucker rats. Biochemical Journal 186 525-534.

Ebina T, Araki E, Taira M, Shimada F, Mori M, Craik CS, Siddle K, Piesce SB \& Roth RA 1987 Replacement of lysine residue 1030 in the putative ATP binding region of the insulin receptor abolishes insulin- and antibody-stimulated glucose and receptor kinase activity. Proceedings of the National Academy of Sciences of the USA $\mathbf{8 4}$ 704-708.

Egan JJ, Saltis J, Wek SA, Simpson IA \& Londos C 1990 Insulin, oxytocin, and vasopressin stimulate protein kinase $\mathrm{C}$ activity in adipocyte plasma membranes. Proceedings of the National Academy of Sciences of the USA 87 1052-1056.

Endeman GK, Yonezawa K \& Roth RA 1990 Phosphatidylinositol kinase or an associated protein is a substrate for the insulin receptor tyrosine kinase. Journal of Biological Chemistry 265 396-400.

Escobedo JA, Navankasattusas S, Kavanaugh WM, Milfay D, Fried VA \& Williams LT 1991 cDNA cloning of a novel $85 \mathrm{kDa}$ protein that has $\mathrm{SH} 2$ domains and regulates binding of PI 3-kinase to the PDGF $\beta$-receptor. Cell 65 75-82.

Farese RV, Standaert ML, Ishizuka T, Yu B, Hernandez H, Waldron C, Watson J, Farese JP, Cooper DR \& Wickstrom E 1992 Antisense DNA downregulates protein kinase C isoenzymes (beta and alpha) and insulin-stimulated 2-deoxyglucose uptake in rat adipocytes. Antisense Research and Development 1 35-42.

Friedman JE, Sherman WM, Reed MJ, Etton CW \& Dohm GL 1990 Exercise training increases glucose transporter protein GLUT4 in skeletal muscle of obese Zucker $(f a / f a)$ rats. FEBS Letters $\mathbf{2 6 8}$ $13-16$. 
Frohman MA, Dush MK \& Martin GR 1988 Rapid production of full-length cDNAs from rare transcripts: amplification using a single gene-specific oligonucleotide primer. Proceedings of the National Academy of Sciences of the USA 85 8998-9002.

Hayashi H, Kamohara S, Nishioka Y, Kanai F, Miyake N, Fukui Y, Shibasaki F, Takenawa T \& Ebina Y 1992. Insulin treatment stimulates the tyrosine phosphorylation of the $\alpha$-type $85-\mathrm{kDa}$ subunit of phosphatidylinositol 3-kinase in vitro. Journal of Biological Chemistry $26722575-22580$.

Heydrick SJ, Jullien D, Gautier N, Tanti J-F, Giorgetti S, Van Obberghen E \& Le Marchand-Brustel Y 1993 Defect in skeletal muscle phosphatidylinositol-3-kinase in obese insulin-resistant mice. Journal of Clinical Investigation 91 1358-1366.

Hiles I D, Otsu M, Volinia S, Fry MJ, Dhand R, Panayotou G, Ruitz-Larrea F, Thompson A, Totty NF, Husan JJ, Courtneidge SA, Parker PJ \& Waterfield MD 1992 Phosphatidylinositol 3-kinase: structure and expression of the $110 \mathrm{kDa}$ catalytic subunit. Cell 70 419-429.

Hoffman JM, Ishizuka T \& Farese RV 1991 Interrelated effects of insulin and glucose on diacylglycerol-protein kinase-C signalling in rat adipocytes and solei muscle in vitro and in vivo in diabetic rats. Endocrinology 128 2937-2948.

Ishizuka T, Cooper DR \& Farese RV 1989 Insulin stimulates the translocation of protein kinase $\mathrm{C}$ in rat adipocytes. FEBS Letters 257 $337-340$.

Ishizuka T, Cooper DR, Hernandez HD, Buckley M, Standaert ML \& Farese RV 1990 Effects of insulin on diacylglycerol-protein kinase $\mathrm{C}$ signaling in rat diaphragm and soleus muscles and relationship to glucose transport. Diabetes 39 181-190.

Ishizuka T, Cooper DR, Arnold T, Hernandez H \& Farese RV 1991 Downregulation of protein kinase $\mathrm{C}$ and insulin-stimulated 2-deoxyglucose uptake in rat adipocytes by phorbol esters, glucose, and insulin. Diabetes 40 1274-1281.

Ishizuka T, Yamamoto M, Kajita K, Nagashima T, Yasuda K, Miura K, Cooper DR \& Farese RV 1992 Insulin stimulates novel protein kinase $\mathrm{C}$ in rat adipocytes. Biochemical and Biophysical Research Communications 183 814-820.

Ishizuka T, Yamamoto M, Kajita K, Yasuda K, Miura K, Hernandez H \& Farese RV 1993 Differential effect of aging on protein kinase $\mathrm{C}$ activity in rat adipocytes and soleus muscle. Metabolism $\mathbf{1 4 2}$ $420-425$.

Kanai F, Ito K, Todaka M, Hayashi H, Kamohara S, Ishii K, Okada T, Hazeki O \& Ui M 1993 Insulin-stimulated GLUT4 translocation is relevant to the phosphorylation of IRS-1 and the activity of PI 3-kinase. Biochemical and Biophysical Research Communications 195 762-768.

Kawano K, Hirashima T, Mori S, Saitoh Y, Kurosumi M \& Natori T 1992 Spontaneous long-term hyperglycemic rat with diabetic complications. Otsuka Long-Evans Tokushima fatty (OLETF) strain. Diabetes 41 1422-1428.

King PA, Horton ED, Hirshman MF \& Horton ES 1992 Insulin resistance in obese Zucker rat $(f a / f a)$ skeletal muscle is associated with a failure of glucose transporter translocation. Journal of Clinical Investigation 90 1568-1575.
King WG, Kucera GL, Sorisky A, Zhang AJ \& Rittenhouse SE 1991 Protein kinase $\mathrm{C}$ regulates the stimulated accumulation of 3-phosphorylated phosphoinositides in platelets. Biochemical Journal 278 475-480.

Kucera GL \& Rittenhouse SE 1990 Human platelets form 3 -phosphorylated phosphoinositides in response to $\alpha$-thrombin, U46619, or GTP $\gamma$ S. Journal of Biological Chemistry 265 5345-5348.

Nishizuka Y 1988 The molecular heterogeneity of protein kinase C and its implications for cellular regulation. Nature 334 661-665.

Obermaier-Kusser B, Muhlbache C, Mushack J, Seffer E, Ermel B, Machicao F, Schmidt F \& Haring HU 1989 Further evidence for a two-step model of glucose-transport regulation. Biochemical Journal 261 699-705.

Olefsky JM 1978 Mechanisms of the ability of insulin to activate the glucose transport system in rat adipocytes. Biochemical Journal 172 $127-145$.

Ono Y, Fujii T, Ogita K, Kikkawa U, Igarashi K \& Nishizuka Y 1989 The structure, expression, and properties of additional members of the protein kinase C family. Journal of Biological Chemistry 263 6927-6932.

Preiss J, Loomis C, Bishop W, Stein R, Niedel J \& Bell M 1986 Quantitative measurement of sn-1,2-diacylglycerols present in platelets, hepatocytes, and ras- and sis-transformed normal rat kidney cells. Journal of Biological Chemistry 261 8597-8600.

Rodbell M 1964 Metabolism of isolated fat cells. Journal of Biological Chemistry 239 375-380.

Ruderman NB, Kapeller R, White MF \& Cantley LC 1990 Activation of phosphatidylinositol 3-kinase by insulin. Proceedings of the National Academy of Sciences of the USA 87 1411-1415.

Sato T, Asahi Y, Toide K \& Nakayama N 1994 Insulin resistance in skeletal muscle of the male Otsuka Long-Evans Tokushima Fatty rat, a new model of NIDDM. Diabetologia 38 1033-1041.

Traynor-Kaplan AE, Thompson BL, Harris AL, Taylor P, Omann GM \& Sklar LA 1989 Transient increase in phosphatidylinositol trisphosphate during activation of human neutrophils. Journal of Biological Chemistry 264 15668-15673.

Van de Werve G, Zaninette O, Lang U, Vallotton MB \& Jeanrenaud B 1987 Identification of a major defect in insulin-resistant tissues of genetically obese $(f a / f a)$ rats. Diabetes 36 310-314.

Varticovski L, Druker B, Morrison D, Cantley LC \& Roberts T 1989 The colony stimulating factor- 1 receptor associates with and activates phosphatidylinositol-3 kinase. Nature 342 699-702.

Voliovitch H, Schindler DG, Hadari YR, Taylor SI, Accili D \& Zick Y 1995 Tyrosine phosphorylation of insulin receptor substrate-1 in vivo depends upon the presence of its pleckstrin homology region. Journal of Biological Chemistry 270 18083-18087.

Whitman M, Kaplan D, Roberts T \& Cantley L 1987 Evidence for two distinct phosphatidylinositol kinases in fibroblasts. Implications for cellular regulation. Biochemical Journal 247 165-174.

Received 28 January 1997

Revised manuscript received 13 May 1997

Accepted 25 July 1997 